\title{
Significance of Conversation between Mast Cells and Nerves
}

\author{
Hanneke P. M. van der Kleij, MD; \\ John Bienenstock, CM, MD (Hon), FRCP, FRCP(C), FRSC
}

\begin{abstract}
More and more studies are demonstrating interactions between the nervous system and the immune system. However, the functional relevance of this interaction still remains to be elucidated. Such associations have been found in the intestine between nerves and mast cells as well as between eosinophils and plasma cells. Similar morphologic associations have been demonstrated in the liver, mesentery, urinary bladder, and skin. Unmyelinated axons especially were found to associate with mast cells as well as Langerhans' cells in primate as well as murine skin. Although there are several pathways by which immune cells interact with the nervous system, the focus in this review will be on the interaction between mast cells and nerves.
\end{abstract}

Functional communication between mast cells and nerves has been shown to occur in a variety of both physiologic and pathologic situations. ${ }^{1,2}$ Neuronal mechanisms are involved in mast cell activation, and mast cells act as principle transducers of information between peripheral nerves and local inflammatory events. Neuropeptides, released from autonomic or nonadrenergic noncholinergic nerves, may influence the recruitment, proliferation, and activation of leukocytes. On the other hand, inflammatory cells may modulate the neuronal phenotype and function.

\section{Association of Mast Cells and Nerves}

It is well established that there is an anatomic association between mast cells and nerves in most

H. P. M. van der Kleij, J. Bienenstock-Brain-Body Institute and Department of Pathology and Molecular Medicine, St. Joseph's Healthcare, Hamilton, Ontario, and McMaster University, Hamilton, Ontario

Correspondence to: John Bienenstock, Department of Pathology and Molecular Medicine, McMaster University, 1200 Main Street West, Hamilton, Ontario, L8N $3 Z 5$ Canada tissues..$^{3-6}$ In various studies, tissue mast cells invariably showed ultrastructural evidence of activation even in normal healthy conditions, suggesting that these cells are constantly providing information to the nervous system. Mutual associations between nerves and mast cells have been observed in normal conditions and in pathologic ones such as human irritable bowel syndrome, atopic dermatitis, and interstitial cystitis. ${ }^{7}$ A morphometric study in both infected and healthy rat intestine showed that mast cells and nerves were closely and invariably approximated in rat intestinal villi. ${ }^{8}$ Electron microscopy showed evident membrane-membrane association between mucosal mast cells and nerves with dense core vesicles at the points of contact. Other than in the intestine, nerve and mast cell associations are found in rat trachea and peripheral lung tissue, ${ }^{9}$ skin, ${ }^{10}$ urinary bladder, ${ }^{11}$ brain, ${ }^{12}$ and several other tissues..$^{13,14}$

Besides an anatomic association, there is a functional bidirectional communication pathway in vivo. For example, psychological stress in rats causes increased chloride ion secretion by the intestinal epithelium, increased colonic mucin 
secretion, and increased intestinal permeability, mediated in part by both mast cells and substance P. ${ }^{15-17}$ Furthermore, mast cells and substance $\mathrm{P}$-containing nerves are also obligatory components in a hapten-induced model of lung inflammation. ${ }^{18}$ Rozniecki and colleagues provided evidence for morphologic, anatomic, and functional interactions of dura mast cells with cholinergic and peptidergic neurons containing substance $\mathrm{P}$ and calcitonin gene-related peptide. ${ }^{19}$

\section{Mast Cells}

Mast cells are widely distributed throughout the body in both connective tissue and at mucosal surfaces. They form a heterogeneous population of cells with differences in their development, mediator content, and their ability to interact with the local environment..$^{20}$ Therefore, it seems likely that mast cells have many diverse functions. They are thought to play a major role in resistance to infection and are extensively involved in inflammation and subsequent tissue repair. ${ }^{21}$ Moreover, there is evidence to support the concept that mast cells are functionally important modulators of hair follicle cycling, specifically during anagen development. ${ }^{22}$ This invites the exploration of the murine hair cycle as a model for dissecting the physiologic growth modulatory functions of mast cells. ${ }^{23}$ Furthermore, mast cells are known to have a significant variety of actions and interactions with other cells and physiologic systems.

Mast cells can be divided into various subpopulations with distinct phenotypes. Mast cell secretory granules contain unique tryptic and chymotryptic serine proteases that differ between species and tissues. The heterogeneity can express itself as differences in histochemical, biochemi$\mathrm{cal}$, and functional characteristics. The growth factors required for human mast cell differentiation have been shown to be somewhat different than those for such differentiation in rodents. ${ }^{24}$ Although tryptase(s) is found in most or every human mast cell, just a single chymase has been defined. Human mast cells are classified by the presence or relative absence of this chymase. ${ }^{25}$ In contrast, rodent mast cell subsets store different chymase isoforms. Two main subsets, connective tissue-type mast cells (CTMCs) and mucosal mast cells (MMCs), are recognized as distinct mast cell populations with different phenotypic and functional characteristics. ${ }^{26,27}$ Another commonly used classification uses the terms "MCt" and "MCtc"; the MCt phenotype contains tryptase alone whereas the MCtc phenotype contains chymase and tryptase. ${ }^{28}$

In spite of their variation, the different mastcell subsets are derived from a common precursor in the bone marrow. Mast cell progenitor cells translocate from bone marrow to mucosal and connective tissues to locally undergo differentiation into mature forms. They possess a remarkable degree of plasticity, so that even apparently fully differentiated CTMCs will transform their phenotype to that of MMCs if transplanted into a mucosal environment. ${ }^{29}$

\section{Mast Cell Mediators}

Mast cells are capable of the synthesis of a large number of pro- and anti-inflammatory mediators, including cytokines, growth factors and products of arachidonic acid metabolism. Pre-stored mediators, such as histamine, serine proteases, proteoglycans, sulphatases, and tumour necrosis factor (TNF), are released within minutes after degranulation of the cell. ${ }^{30}$ After this primary response, a second wave of newly synthesized mediators are released, including prostaglandins and leukotrienes. In the late-phase allergic response, cytokines such as interleukin (IL)-4, IL-5, IL-6, IL-8, IL-13, and TNF are induced and secreted.$^{30}$ Expression of this host of cytokines has led to the assumption of a role for mast cells in host defense, for example, in immunoglobu$\operatorname{lin} \mathrm{E}$ ( $\mathrm{IgE}$ )-dependent immune responses to certain parasites, in natural immunity to bacterial infections, and in inflammatory and allergic diseases.

The communication between mast cells and nerves via cytokines has not received much attention. TNF, which is pre-stored and is released rapidly on degranulation, has an important functional effect. Mast cells also secrete newly 
synthesized TNF within 30 minutes following certain stimuli. ${ }^{31}$ Furthermore, TNF is able itself to induce mast cell degranulation. TNF is involved in changing neuronal cell function because it can modulate the susceptibility of neurons to electrical stimuli. The sensitizing effect of TNF seems to primarily target $\mathrm{C}$ fibres. ${ }^{32}$ In vitro incubation of rat sensory nerves with TNF enhanced the response of $\mathrm{C}$ fibres to capsaicin. ${ }^{33} \mathrm{It}$ is known that TNF can activate nerve endings, causing a lowering of the threshold to stimulation. A study by Aranguez and colleagues indicated that mouse astrocytes express TNF receptor 1 (TNFR1). ${ }^{34}$ Furthermore, rat microglia transcribe messenger ribonucleic acid (mRNA) for both TNFR1 and TNFR2. ${ }^{35}$ These results indicate that neuronal tissue probably expresses both TNF receptors and implies that communication between mast cells and nerves may be mediated, at least in part, by TNF.

Another major mast cell mediator is tryptase, known to be present in all mast cell subtypes. Although proteases (tryptase, chymase) are not classified as cytokines, they have many cytokinelike effects. These cytokine-like activities often activate cells via protease-activated receptors (PARs), cleavage of which results in signal transduction. ${ }^{36}$ Proteases regulate neurons and glia in the central nervous system by cleaving PAR. Myenteric neuron protease-activated receptor 2 (PAR2) expression has been detected by reverse transcription polymerase chain reaction. Tryptase has recently been shown to cleave PAR2 on primary spinal afferent neurons, which causes the release of substance $\mathrm{P}$, activation of the neurokinin 1 receptor, and amplification of inflammation and thermal and mechanical hyperalgesia. ${ }^{37}$ Corvera and colleagues showed that purified tryptase stimulates calcium mobilization in myenteric neurons. ${ }^{38}$ They hypothesized that tryptase excites neurons through PAR2 because activation of PAR2 with trypsin or peptide agonists strongly desensitizes the response to tryptase. In addition, a tryptase inhibitor suppressed calcium mobilization in response to degranulated mast cells. This indicates that tryptase is a major mast cell mediator with the capacity of activating myenteric neurons through PAR2.

\section{Growth Factors}

The classic mediators of inflammation are not alone in their ability to influence the interaction between mast cells and nerves. Nerve and mast cell growth factors are thought to play prominent regulatory roles as well. One such factor, nerve growth factor (NGF), acts as a chemoattractant, thereby causing an increase in the number of mast cells as well as their degranulation. ${ }^{39-41}$ NGF receptors on mast cells act as autoreceptors, regulating mast cell NGF synthesis and release while at the same time being sensitive to NGF from the environment. Inflammation can lead to an enhanced production and release of NGF. In turn, NGF induces the expression of neuropeptides and lowers the threshold of neurones for firing. ${ }^{41}$

In vivo administration of NGF in neonatal rats caused a great increase in the size and number of mast cells in the peripheral tissues. ${ }^{42}$ Furthermore, NGF has been shown to induce degranulation and histamine release from mast cells. ${ }^{43,44}$ To complete the circle, mast cells are capable of producing NGF. ${ }^{45}$ Therefore, it is not surprising that injection of NGF causes mast cell proliferation, in part by mast cell degranulation. ${ }^{46}$

NGF can have proinflammatory as well as anti-inflammatory effects, depending on the situation and on the concentration of the compound. Braun and colleagues recently showed that nasal treatment of mice with NGF induced airway hyperresponsiveness as measured by electrical field stimulation. ${ }^{47}$ Another study by Braun and colleagues showed that nasal treatment of mice with anti-NGF prevented the development of airway hyperresponsiveness. ${ }^{48}$ On the other hand, the expression of NGF is increased after brain injury. There is evidence that the increased production of NGF in the central nervous system during brain disease such as multiple sclerosis can suppress inflammation by switching the immune response to an anti-inflammatory suppressive model. ${ }^{49}$ In a compelling study, the injection of $\mathrm{CD}^{+}$lymphocytes transfected with the $N G F$ gene, either before or after the induction of allergic encephalomyelitis, inhibited the onset of demyelination..$^{50}$ This powerful inhibition of an autoimmune process showed that local expression 
of NGF prevented the migration of inflammatory cells across the epithelium.

\section{Mast Cell Activation by Tachykinins: Expression of the Neurokinin 1 Receptor}

In addition to the classic neurotransmitters acetylcholine and noradrenaline, a wide number of peptides with neurotransmitter activity have been identified in the past few decades. Among them, the tachykinins substance $\mathrm{P}$, neurokinin $\mathrm{A}$, and neurokinin $\mathrm{B}$ appear to act as mediators of nonadrenergic noncholinergic excitatory neurotransmission.

The tachykinin substance $P$ can activate mast cells via distinct mechanisms. First, substance $\mathrm{P}$ can activate mast cells without an intermediary receptor through direct combination with $\mathrm{G}$ proteins on the cell surface..$^{51,52}$ Second, tachykinins interact with specific membrane proteins belonging to the family of $G$ protein-coupling cell membrane receptors. Three distinct tachykinin receptor subtypes have been identified and are denoted as neurokinin 1 (NK1), neurokinin 2 (NK2), and neurokinin 3 (NK3); these receptors have the highest affinity for substance $\mathrm{P}$, neurokinin A, and neurokinin B, respectively. ${ }^{53-55}$ Several investigators have discussed the increased in vivo expression of NK1 receptor in inflamed tissue. ${ }^{56,57}$ Therefore, it can be proposed that NK1 receptor expression on immune cells such as mast cells is influenced by environmental inflammatory factors such as cytokines. In previous work, Karimi and colleagues demonstrated the increased sensitivity of bone marrow-derived mast cells (BMMCs) to substance $\mathrm{P}$ after a short coculture with the cytokines IL-4 and stem cell factor. ${ }^{58}$

The NK1 receptor appears to be present on the basophil leukemia cell line (RBL) ${ }^{59}$ Similar findings were made in rat peritoneal mast cells, which also express NK1 receptors. ${ }^{60}$ In an in vitro coculture model, the activation of nerves with scorpion venom elicited the degranulation of RBL cells via substance $\mathrm{P}{ }^{61}$ It was shown that this substance-P activation is initiated only at the point of contact between nerve fibres and associated RBL cells through NK1 receptors. ${ }^{62}$
Recently, it has been shown that functional expression of NK1 receptors on BMMCs (which are phenotypically immature mast cells) varies according to culture conditions. The extent of degranulation of BMMCs depends directly on both the concentration of substance P used and the amount of NK1 receptor expression. ${ }^{63}$ Similarly, in an in vitro coculture model of BMMCs and neurites, we showed that expression of NK1 by mast cells lowers the threshold of activation induced by nerve stimulation ${ }^{64}$ Furthermore, the response in coculture was inhibited by pretreatment with SR140333, an NK1-specific receptor antagonist strongly pointing to an NK1 receptor-dependent mechanism.

Very recently, Bischoff and colleagues examined the expression of tachykinin receptors on human mast cells and found that human mast cells derived from intestinal mucosa do not constitutively express NK1, NK2, or NK3 receptors. ${ }^{65}$ However, when stimulated by IgE receptor crosslinking, these mast cells started to express NK1 receptors but not NK2 or NK3 receptors, again suggesting that specific tissue conditions such as allergic inflammation may lead to mast cell expression of NK1 receptors.

\section{Interaction of Mast Cells and Nerves}

Mast cells and nerves are in constant contact with each other in both physiologic and pathologic situations. Many arguments suggest that mast cells and nerves may be seen as a functional unit. They share a number of activating signals, for some of which both cells express receptors (such as vanilloids). ${ }^{66}$ Furthermore, both mast cells and nerves respond to stimulation by degranulating preformed mediators, many of which are produced by both cells (NGF, neuropeptides, and endothelin-1). Mast cells can be activated by neuropeptides such as substance P, and many mast cell mediators, including serotonin and tryptase, can cause the release of tachykinins from sensory nerve endings. ${ }^{3,67-69}$ Moreover, mast cells and nerves cooperate in a number of pathologic and physiologic processes such as the regulation of hair follicle cycling and development and such as wound 
healing. ${ }^{70,71}$ Also, stress has been shown to trigger skin mast cell degranulation, an action not only dependent on corticotropin-releasing hormone but apparently also involving substance $\mathrm{P} \cdot{ }^{72}$ Stimulation of the enteric nervous system by mast cell activation is likely to play an important role in mast cell-mediated host defense in infections, especially infections induced by bacteria. ${ }^{21,73}$ Interactions between mast cells and nerves have also been interpreted as important neuronal tissue repair mechanisms following injury..$^{71,74}$

An enhanced interaction between mast cells and nerves can lead to neurogenic inflammation. Inflammatory models have shown a significant increase in the number of mast cells, resulting in the increased release of inflammatory mediators on degranulation. Inflammatory mast cell mediators may modulate sensory nerves through the activation of receptors on nerve terminals (Figure 1). Nonadrenergic noncholinergic (NANC) nerve endings express receptors for histamine (H1 and $\mathrm{H} 3$ ) and serotonin (5HT2A). ${ }^{75-77}$ Under inflammatory-like conditions, primary NANC nerves show an up-regulation of at least histamine $\mathrm{H} 1$ receptor expression. ${ }^{78} \mathrm{~A}$ recent report by Shubayev and Myers provides evidence of expression of TNFR1 and TNFR2 in dorsal root ganglia (DRG) neurons in adult rats. ${ }^{79}$ Both receptor subtypes were up-regulated in DRG neurons during inflammation. Capsaicin-sensitive nerves can be altered in this way and could result in an increased release of neuropeptides. Allergen/hapten challenge can also lead to production of substance $\mathrm{P}$ in a subset of sensory nerve fibres that are typically devoid of neuropeptides. In other words, allergen/hapten challenge leads to a phenotypic switch in the sensory neuropeptide innervation in the airways, probably via mast cell activation, again increasing the interaction between mast cells and substance $\mathrm{P}$-immunoreactive nerves.$^{80,81}$ Thus, mast cell activation can result in an increase in the excitability of sensory nerves and the production and secretion of neuropeptides.

\section{Neurogenic Inflammation}

Neurogenic inflammation involves a change in function of sensory neurons owing to inflamma-

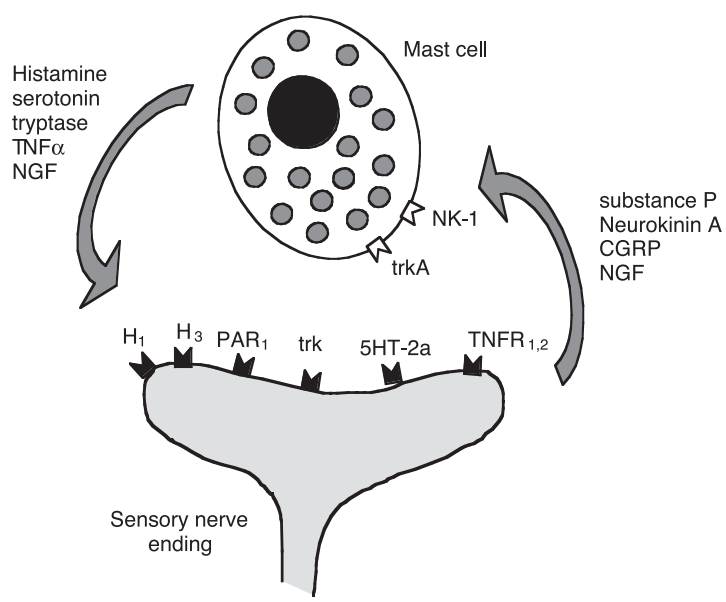

Figure 1 Mast cell-nerve interactions. Inflammatory mediators may modulate sensory nerve endings through the activation of receptors on nerve terminals. Neuropeptides can stimulate mast cells via a receptordependent and a receptor-independent mechanism. Under inflammatory-like conditions, receptor expression on nerve endings and mast cells can be up-regulated. $\mathrm{CGRP}=$ calcitonin gene-related peptide; $\mathrm{H}=$ histamine; $5 \mathrm{HT} 2 \mathrm{~A}=$ serotonin $2 \mathrm{a} ; \mathrm{NGF}=$ nerve growth factor; NK-1 = neurokinin 1; PAR = protease-activated receptor; TNFR $=$ tumour necrosis factor receptor; trk $=$ neurotrophin tyrosine kinase receptor.

tory mediators, inducing an enhanced release of neuropeptides from the sensory nerve endings. ${ }^{82}$ Neurogenic inflammation has been shown to occur in different tissues, including the skin, urinary tract, digestive system, and airways. ${ }^{83-86}$ Given the close proximity of mast cells and nerves to blood vessels in most tissues, they may be considered an important functional unit in neurogenic inflammation. ${ }^{3}$

It is becoming apparent that by affecting neuronal functioning, the mast cell and its mediators play an important role in neurogenic inflammation. ${ }^{3,87}$ Mast cells pass information on through afferent nerves to local tissues by axon reflexes and to the spinal cord and thence the brain. Stimulation of $\mathrm{C}$ fibres by a range of chemical and physical factors results in afferent neuronal conduction that elicits parasympathetic reflexes and antidromic impulses travelling to the peripheral nerve terminal. Axon reflexes account for many of the local physiologic responses to antigen (for instance, in sensitized lung and gut tissues) and have long 
been recognized to be involved in local vasodilatation in the skin. ${ }^{88-91}$ Antidromic stimulation of guinea pig vagal sensory fibres results in contractions of the isolated airway smooth muscle, mediated by tachykinins. ${ }^{92}$ Further studies indicate that neuropeptide release can also be induced via direct depolarization of the nerve terminal. ${ }^{93}$

\section{Priming}

It is widely accepted that the effect of substance $\mathrm{P}$ as a mast cell secretagogue is found only at high concentrations. However, exposure of mast cells to very small amounts of this neuropeptide may be expected to reduce the threshold of activation of the cells for subsequent challenge with antigen or neuropeptides. Therefore, mast cells can be primed when exposed to physiologically relevant low concentrations of substances, which lowers their thresholds to subsequent activation.

Priming appears to be a broadly based biologic process and has been reported in several cell types. Mast cells have been reported to be primed by different cytokine growth factors for activation by different agonists. ${ }^{94}$ Stem cell factor (SCF), for instance, can act as a priming agent in some circumstances. ${ }^{95}$ We have shown that SCF and IL-4 prime BMMCs to induce increased responsiveness to substance P. ${ }^{63}$ Mast cells can also be primed by substance $P$ itself because repeated doses of very low concentrations (picomolars) of substance $\mathrm{P}$ can induce mast cell degranulation and can lower the threshold for degranulation via subsequent crosslinking of IgE receptors by anti-IgE. ${ }^{96}$ The concept of priming also applies to neurons. TNF may exert a priming effect (rather than a direct stimulatory effect) on sensory activity. ${ }^{33,97}$

\section{Mast Cell Activation versus Mast Cell Degranulation}

Exocytosis is the most obvious event associated with secretion of the mediator molecules contained in granules. It used to be believed that mast cell activation was "all or nothing" and that IgE cross-linking induces the functional consequences of allergic reactions and anaphylaxis. However, the activity of mast cells in health and disease is clearly much more complicated. Secretion can occur without evidence of degranulation, and even molecules stored within the same granules can be released and secreted in a discriminatory pattern..$^{98}$

Mast cells have been increasingly implicated in inflammatory processes in which explosive degranulation is not commonly observed. A study by Ratliff and colleagues ultrastructurally showed mast cells in close proximity to unmyelinated nerve fibres. ${ }^{99}$ These mast cells contained granules showing ultrastructural features of activation or piecemeal degranulation, which have been associated with differential secretion. Furthermore, Gottwald and colleagues found increases in the histamine content of intestinal tissues after electrical vagal stimulation without degranulation of mast cells. ${ }^{100}$ These data support the potential for intestinal mucosal mast cell regulation by the central nervous system and suggest modulation of mast cells without degranulation. Furthermore, IL-1 stimulates secretion of IL- 6 without release of the granule-associated protease tryptase. ${ }^{101}$ Selective secretion of IL- 6 from mast cells appears to be distinct from degranulation and may contribute to the development of inflammation, in which the importance of IL-6 has been recognized. Serotonin can be released separately from histamine, and differential synthesis and release of arachidonic acid metabolites, prostaglandins, and leukotrienes have been reported. ${ }^{102,103}$

\section{Interaction of Mast Cells and Nerves in Tissues}

\section{Brain and Immune System}

The brain and the nervous and immune systems are the major adaptive systems of the body. ${ }^{104}$ Several pathways have been shown to link the brain and the immune system, such as (1) the autonomic nervous system via direct neural influences and (2) the neuroendocrine humoral outflow via the pituitary. Corticotropin-releasing hormone $(\mathrm{CRH})$, secreted by the pituitary gland, is a major regulator of the hypothalamic-pituitary-adrenal 
(HPA) axis and cortisone synthesis and acts as a coordinator of the stress response. ${ }^{105} \mathrm{CRH}$ is also thought to be involved peripherally in tissue responses to stress in the skin, respiratory tract, and intestine.

Mast cells are resident in the brain of many species. ${ }^{106}$ They appear to enter the brain via penetrating blood vessels. Brain mast cells are associated with blood vessels throughout the brain and especially in the meninges. ${ }^{107}$ They seem to be involved in behavioural activity, such as the courting behaviour of doves. ${ }^{108}$ Large numbers of tryptase-containing mast cells have been described as surrounding the pituitary gland and are thought to act as an immune gate for HPA axis activity. ${ }^{109}$ These mast cells can respond to antigens and regulate CRH secretion via histamine effects. ${ }^{105}$

The physiologic significance of mast cells in brain function and/or metabolism is unclear. However, they can modulate neuroendocrine control systems, ${ }^{2}$ and they could play a role in the regulation of meningeal blood flow and vessel permeability. ${ }^{110}$ Pavlovian conditioning has also been shown to be able to promote mast cell degranulation through as yet unknown mechanisms. ${ }^{111}$

Apart from their being resident cells, mast cells can move through the brain in the absence of inflammation. Mast cells in the central nervous system may participate in the regulation of inflammatory responses through interactions with the HPA axis. Matsumoto and colleagues showed that in the dog, degranulation of mast cells evoked HPA activation in response to histamine release. ${ }^{109}$ The physiologic effects of psychological stress are often largely mediated by $\mathrm{CRH}$, released either centrally or peripherally, and mast cell-nerve interactions are important components of this response. ${ }^{112}$ In response to psychological stress or certain physical stressors, an inflammatory process may occur through the release of neuropeptides (especially substance $\mathrm{P}$ ) from sensory nerves and the activation of mast cells or other inflammatory cells. Central neuropeptides initiate a systemic stress response by activation of neuroendocrine pathways (such as the sympathetic nervous system, the hypothalamic-pituitary axis, and the renin-angiotensin system) with the release of stress hormones (ie, catecholamines, corticosteroids, growth hormone, glucagons, and renin) ${ }^{113}$ These effects have been found in a variety of stress models, including cold, restraint stress, and water avoidance stress. ${ }^{15,114,115}$

\section{The Skin}

The dermis is richly innervated by primary efferent sensory nerves, postganglionic cholinergic parasympathetic nerves, and postganglionic adrenergic and cholinergic sympathetic nerves. ${ }^{116} \mathrm{Neu}-$ ropeptides, released by cutaneous nerves, have been shown to activate a number of target cells, including Langerhans' cells, endothelial cells, and mast cells. ${ }^{117}$ In the skin, neuropeptides are released in response to nociceptive stimulation by pain and by mechanical and chemical irritants, to mediate skin responses to infection, injury, and wound healing. ${ }^{118,119}$ Substance $\mathrm{P}$ is one of the main neuropeptides responsible for the skin reaction characterized by erythema, pain, and swelling. ${ }^{119}$ In addition, substance $P$ can cause the release of histamine ${ }^{120}$ and $\mathrm{TNF}^{121}$ from skin mast cells, which in turn leads to vasodilation.

Interestingly, capsaicin (which releases neuropeptides from nerves) applied to human skin induces the release of chymase within 6 hours and the induction of E-selectin in adjacent microvascular endothelium, events consistent with release of substance $\mathrm{P}$ from axons and subsequent stimulation of cytokine-mediated mast cell interaction with endothelial cells. However, an identical application of capsaicin to human skin grafted onto immunodeficient mice (and thus experimentally lacking in unmyelinated axons) failed to yield similar findings. 5 These results indicate that unmyelinated axons connect Langerhans' cells and dermal mast cells.

Recent studies have suggested that mast cells play a crucial role in the down-regulation of immune responses and the induction of tolerance after exposure of skin to ultraviolet $B$ radiation (UVB). Hart and colleagues reported the involvement of histamine in UVB-induced suppression in mice, and mast cells have been shown to be the source of UVB-induced histamine. ${ }^{122,123}$ Furthermore, interactions between mast cells and the nervous system appear to be involved in UVBmediated immune suppression. TNF, reported to 
be derived from mast cells, is a major cytokine implicated in signalling the immunosuppressive effects of UVB. ${ }^{124}$ Evidence indicates that mast cells are triggered to release TNF in response to the neuropeptide calcitonin gene-related peptide (CGRP), which is released from UVB-damaged cutaneous nerve endings. ${ }^{125}$

\section{Airways}

Efferent and afferent autonomic nerves regulate many aspects of human and animal airway function. In addition to cholinergic and adrenergic innervation, the NANC nervous system is an important third neural network in the lung. Inhibitory NANC nerves contain vasoactive intestinal peptide (VIP) and nitric oxide, which are potent relaxants of the airways and which counteract bronchoconstriction.

Excitatory NANC nerves or so-called sensory nerves are mainly localized in and beneath the airway epithelium. Tachykinins and CGRP are the predominant excitatory NANC neuropeptides in the airways. ${ }^{126}$

Mast cells lining the mucosal layer of the respiratory tract have been found in close proximity to substance P-immunoreactive and CGRPimmunoreactive nerves of rat trachea and peripheral lung tissue..$^{10}$ Immunohistochemical studies of neuronal tachykinins in the airways of asthmatic patients have yielded conflicting results. Whereas an increase in both the number and length of tachykinin-immunoreactive nerve fibres in the airways was found in some studies, other studies detected significantly less substance P-like immunoreactivity in lung tissue from asthmatic patients as compared to nonasthmatic patients. ${ }^{127-130}$ However, this latter finding may reflect an augmented release of substance $\mathrm{P}$ followed by degradation. Studies on autopsy tissue ${ }^{130}$ plasma levels, ${ }^{131}$ lung lavage fluid, ${ }^{128}$ and sputum ${ }^{132}$ suggest that tachykinins are present in increased amounts in asthmatic airways.

Neuropeptides influence the recruitment, proliferation, and activation of inflammatory cells such as mast cells. There is growing evidence that tachykinins and CGRP are involved in neurogenic inflammation of the airways. Structural studies show that mast cells associate with nerves in the lung. Furthermore, Forsythe and colleagues have demonstrated that substance $\mathrm{P}$ and neurokinin $\mathrm{A}$ induce histamine release from human airway mast cells. ${ }^{133}$ Moreover, antigen causes a secretory response in the rat trachea via an interaction dependent on mast cells and nerves. ${ }^{89}$

\section{Gastrointestinal Tract}

The gastrointestinal tract is characterized by a unique accumulation of immune and inflammatory cells. The mechanism of interaction between nerve and inflammatory cells in the intestine is, however, very unclear. Intestinal mast cells have been repeatedly reported to communicate with the enteric nervous system. Furthermore, Stead and colleagues, on the basis of electron microscopy studies, reported an anatomic association between mast cells and nerves in the human intestinal mucosa. ${ }^{134}$

Nerve stimulation has been reported to cause mast cell degranulation in the intestine. First, Shanahan and colleagues showed that substance $P$ caused mediator release from intestinal mucosal mast cells. ${ }^{135}$ Subsequently, substance $P$ and CGRP fibres have been reported to activate peptidergic mast cells in the intestinal mucosa of healthy and infected rats as well as in patients with inflammatory bowel disease. ${ }^{1}$

Mast cell mediators also appear to have an effect on the nerves in the intestine. Intestinal mast cell infiltration may perturb nerve function, leading to abdominal pain perception in patients with irritable bowel syndrome (IBS). ${ }^{136}$ Recent evidence for activated mast cells associated with enteric nerves in IBS strongly implies that mast cells are involved in this symptom complex. ${ }^{136} \mathrm{~A}$ study by Jiang and colleagues using an intestinal model for anaphylaxis showed that serotonin and histamine, released from the mast cells after intestinal anaphylaxis, stimulate mesenteric afferents via 5-HT3 and histamine $\mathrm{H} 1$ receptors. ${ }^{137}$ Mesenteric afferent-nerve discharge increased approximately 1 minute after luminal antigen challenge and was attenuated by serotonin and histamine receptor antagonists. Mast cell-nerve association appears to function as a homeostatic unit in the regulation of gut physiology and in response to antigens. ${ }^{138}$ 
Perdue and colleagues determined the existence of an integral nerve-to-mast cell and mast cell-to-nerve connection during intestinal anaphylaxis. ${ }^{139}$ A role for the mast cell-to-nerve connection was established by increases in the shortcircuit current after antigen challenge. The response to antigenic stimulation was reduced in mast cell-deficient $\mathrm{W} / \mathrm{Wv}$ mice as compared to their $+/+$ litter mates and was inhibited by different mast cell antagonists in $+/+$ mice but not in $\mathrm{W} / \mathrm{Wv}$ mice, pointing to a mast cell-to-nerve connection. Furthermore, reconstitution of the mast cell deficiency was followed by a restoration of the neural response. In sensitized guinea pig intestine, the short-circuit-current secretory response to antigen occurred simultaneously with acetylcholine release and could be blocked by atropine. ${ }^{140}$ This showed conclusively that nerve excitation and the secretion of the main cholinergic neurotransmitter could be induced by antigen via mast cells through an immune-mediated response. The effects of Clostridium difficile toxin on intestinal segments has also been shown to be dependent on intact mast cells and substance $\mathrm{P}$-containing nerves. ${ }^{141,142}$

It can be reasonably concluded that nerves and mast cells form a physiologic unit that presumably maintains and regulates homeostasis of the mucosal epithelial secretory response. This unit is involved in health, in response to stress, and also in response to injuries and environmental pathogens.

\section{Therapy}

In different tissues and species, there is constant communication between mast cells and the nervous system. This functional communication has been shown to occur in a variety of both physiologic and pathologic situations. ${ }^{6}$ The concept of these interactions is very interesting and may bring about new therapeutic and diagnostic approaches.

In humans, an inhaled long-acting $\beta_{2}$ agonist inhibits mast cell mediator release and plasma exudation and may reduce sensory nerve activation. In combination with a corticosteroid, the low systemic effect of these drugs does not result in any significant adverse effects, and there is a strong scientific rationale for long-term asthma therapy. ${ }^{143}$ In the skin, cyclosporin A has powerful therapeutic effects on severe therapy-resistant atopic dermatitis. ${ }^{144}$ Treating the skin with cyclosporin A increases the stable granule population and results in the disappearance of the close interrelation of mast cells and cutaneous nerves. These findings suggest that cyclosporin A may exert its therapeutic effect by inhibiting mast cell activation and by affecting the interaction between mast cells and nerves.

Exogenous administration of neuropeptides to maintain normal immune defences represents a new field of pharmacotherapeutics against bacterial invasion. But besides this positive health effect of neuropeptides, there is the negative fact that neuropeptides can activate mast cells and result in an enhanced communication between mast cells and nerves, causing an inflammatory response. Mast cell mediators can sensitize sensory neurons, which further activate the mast cells by releasing neurotransmitters or neuropeptides (eg, neurotensin, somatostatin, substance $\mathrm{P}$, and acetylcholine). It has been shown that in the gastrointestinal tract, CGRP, substance $\mathrm{P}$, and VIP-immunoreactive nerve fibres are involved in protection of the tissue. ${ }^{145,146} \mathrm{In}$ a rat colitis model, an early decrease in these neuropeptides may be an essential condition for the development of colitis. That the intensity and density of substance P and VIP-IR nerve fibres increased after the induction of colitis suggests their possible involvement in tissue repair. ${ }^{147}$ Again, on the other hand, these neuropeptides can activate mast cells that play a pivotal role in inflammation. An enhanced interaction between mast cells and nerves can also lead to neurogenic inflammation.

From everything we know so far of the association between mast cells and nerves, it is becoming clearer that the interaction is involved in the regulation of physiologic processes as well as in disease mechanisms. First, therapeutic targets have to be very selective. Because these associations of mast cells and nerves seem to appear throughout the body, it may be very difficult to find a drug that is selectively effective at a particular site in the body. Second, if a selective drug that 
provides protection against disease is found, interference in the cross-communication between mast cells and nerves also increases the risk of changing the healthy balance that is essential for maintaining tissue homeostasis.

More physiologic studies are needed for a better understanding of how the activation of mast cells and nerves is modulated, how sensory nerves control mast cell functions, how mast cells use sensory nerves in inducing inflammation, and the role of nerve fibres and their mediators. New findings will continue to increase our understanding of mast cell-nerve associations and their function in health and disease and will be followed by new therapeutic and diagnostic approaches.

\section{Conclusions}

Extensive crosstalk exists between nerves and mast cells. Although differences in species have been reported, morphologic as well as functional associations are found in most tissues in humans and in rodents. Many of these associations have been shown to occur between substance P- and CGRP-containing neurons and mast cells of all subtypes.

The role of this bidirectional communication between mast cells and nerves appears to be multifactorial. Mast cells are thought to play a major role in resistance to infection and are extensively involved in inflammation and subsequent tissue repair. The communication with the nervous system allows the peripheral and central nervous systems to be involved in the regulation of defence mechanisms, inflammation, and response to infection. The involvement of mast cell-nerve communication in the response to stress, for instance, points to an extensive communication between the nervous and immune systems.

However, the complexity of the picture has increased further as it has become clear that classic neurotransmitters such as acetylcholine and neuropeptides are produced by nonneuronal cells. Nonneuronal cells of the immune system, such as monocytes, macrophages, T lymphocytes, and eosinophils, have been shown to produce endogenous substance P. ${ }^{148,149}$ This alternative source of immune cells could represent an additional source of tachykinins in inflamed tissues, providing a nonneurogenic tachykininergic contribution to the local inflammatory process. ${ }^{150}$

\section{References}

1. Marshall JS, Waserman S. Mast cells and the nerves - potential interactions in the context of chronic disease. Clin Exp Allergy 1995;25: 102-10.

2. van der Kleij HPM, Blennerhassett M, Bienenstock J. Nerve-mast cell interactionspartnership in health and disease. In: Bienenstock J, Blennerhassett M, Goetzl E, editors. Autonomic neuroimmunology. Autonomic Neuroscience Series. Vol. 15. London, (UK): Taylor\&Francis group; 2003 p. 139-170.

3. Purcell WM, Atterwill CK. Mast cells in neuroimmune function: neurotoxicological and neuropharmacological perspectives. Neurochem Res 1995;20:521-32.

4. Arizono N, Matsuda S, Hattori T, et al. Anatomical variation in mast cell nerve associations in the rat small intestine, heart, lung, and skin: similarities of distances between neural processes and mast cells, eosinophils, or plasma cells in the jejunal lamina propria. Lab Invest 1990;62:626-34.

5. Bienenstock J, MacQueen G, Sestini P, et al. Mast cell/nerve interactions in vitro and in vivo. Am Rev Respir Dis 1991;143:S55-8.

6. Pang X, Boucher W, Triadafilopoulos G, et al. Mast cell and substance P-positive nerve involvement in a patient with both irritable bowel syndrome and interstitial cystitis. Urology 1996;47:436-8.

7. Bauer O, Razin E. Mast cell-nerve interactions. New Physiol Sci 2000;15:213-8.

8. Stead RH, Tomioka M, Quinonez G, et al. Intestinal mucosal mast cells in normal and nematode-infected rat intestines are in intimate contact with peptidergic nerves. Proc Natl Acad Sci U S A 1987;84:2975-9.

9. Undem BJ, Riccio MM, Weinreich D, et al. Neurophysiology of mast cell-nerve interactions in the airways. Int Arch Allergy Immunol 1995;107:199-201.

10. Egan CL, Viglione-Schneck MJ, Walsh LJ, et al. Characterization of unmyelinated axons uniting epidermal and dermal immune cells in 
primate and murine skin. J Cutan Pathol 1998;25:20-9.

11. Letourneau R, Pang X, Sant GR, Theoharides TC. Intragranular activation of bladder mast cells and their association with nerve processes in interstitial cystitis. Br J Urol 1996;77:41-54.

12. Keller JT, Marfurt CF. Peptidergic and serotoninergic innervation of the rat dura mater. $\mathrm{J}$ Comp Neurol 1991;309:115-34.

13. Olsson Y. Mast cells in the nervous system. Int Rev Cytol 1968;24:27-70.

14. Newson B, Dahlstrom A, Enerback L, Ahlman $\mathrm{H}$. Suggestive evidence for a direct innervation of mucosal mast cells. Neuroscience 1983; 10:565-70.

15. Pothoulakis C, Castagliuolo I, Leeman SE. Neuroimmune mechanisms of intestinal responses to stress. Role of corticotropinreleasing factor and neurotensin. Ann N Y Acad Sci 1998;840:635-48.

16. Santos J, Saunders PR, Hanssen NP, et al. Corticotropin-releasing hormone mimics stressinduced colonic epithelial pathophysiology in the rat. Am J Physiol 1999;277:G391-9.

17. Santos J, Benjamin M, Yang PC, et al. Chronic stress impairs rat growth and jejunal epithelial barrier function: role of mast cells. Am J Physiol Gastrointest Liver Physiol 2000;278:G847-54.

18. Kraneveld AD, van der Kleij HP, Kool M, et al. Key role for mast cells in nonatopic asthma. J Immunol 2002;169:2044-53.

19. Rozniecki JJ, Dimitriadou V, Lambracht-Hall $\mathrm{M}$, et al. Morphological and functional demonstration of rat dura mater mast cell-neuron interactions in vitro and in vivo. Brain Res 1999;849:1-15.

20. Bradding P, Holgate ST. Immunopathology and human mast cell cytokines. Crit Rev Oncol Hematol 1999;31:119-31.

21. Malaviya R, Ikeda T, Ross E, Abraham SN. Mast cell modulation of neutrophil influx and bacterial clearance at sites of infection through TNF-alpha. Nature 1996;381:77-80.

22. Maurer M, Fischer E, Handjiski B, et al. Activated skin mast cells are involved in murine hair follicle regression (catagen). Lab Invest 1997;77:319-32.

23. Maurer M, Paus R, Czarnetzki BM. Mast cells as modulators of hair follicle cycling. Exp Dermatol 1995;4:266-71.
24. Welle M. Development, significance, and heterogeneity of mast cells with particular regard to the mast cell-specific proteases chymase and tryptase. J Leukoc Biol 1997;61:233-45.

25. Beil WJ, Schulz M, Wefelmeyer U. Mast cell granule composition and tissue location - a close correlation. Histol Histopathol 2000;15:937-46.

26. Befus AD, Dyck N, Goodacre R, Bienenstock J. Mast cells from the human intestinal lamina propria. Isolation, histochemical subtypes, and functional characterization. J Immunol 1987;138:2604-10.

27. Galli SJ. New insights into "the riddle of the mast cells": microenvironmental regulation of mast cell development and phenotypic heterogeneity. Lab Invest 1990;62:5-33.

28. Church MK, Clough GF. Human skin mast cells: in vitro and in vivo studies. Ann Allergy Asthma Immunol 1999;83:471-5.

29. Kitamura Y, Kanakura Y, Sonoda S, et al. Mutual phenotypic changes between connective tissue type and mucosal mast cells. Int Arch Allergy Appl Immunol 1987;82:244-8.

30. Church MK, Levi-Schaffer F. The human mast cell. J Allergy Clin Immunol 1997:99;155-60.

31. Gordon JR, Galli SJ. Mast cells as a source of both preformed and immunologically inducible TNF-alpha/cachectin. Nature 1990:346;274-6.

32. Junger H, Sorkin LS. Nociceptive and inflammatory effects of subcutaneous TNF alpha. Pain 2000;85:145-51.

33. Nicol GD, Lopshire JC, Pafford CM. Tumor necrosis factor enhances the capsaicin sensitivity of rat sensory neurons. J Neurosci 1997; 17:975-82.

34. Aranguez I, Torres C, Rubio N. The receptor for tumor necrosis factor on murine astrocytes: characterization, intracellular degradation, and regulation by cytokines and Theiler's murine encephalomyelitis virus. Glia 1995;13:185-94.

35. Dopp JM, Mackenzie-Graham A, Otero GC, Merrill JE. Differential expression, cytokine modulation, and specific functions of type-1 and type-2 tumor necrosis factor receptors in rat glia. J Neuroimmunol 1997;75:104-12.

36. Mirza H, Schmidt VA, Derian CK, et al. Mitogenic responses mediated through the proteinase-activated receptor- 2 are induced by expressed forms of mast cell alpha- or betatryptases. Blood 1997;90:3914-22. 
37. Defea K, Schmidlin F, Dery O, et al. Mechanisms of initiation and termination of signalling by neuropeptide receptors: a comparison with the proteinase-activated receptors. Biochem Soc Trans 2000;28:419-26.

38. Corvera CU, Dery O, McConalogue K, et al. Thrombin and mast cell tryptase regulate guineapig myenteric neurons through proteinaseactivated receptors-1 and -2. J Physiol 1999; 517:741-56.

39. Marshall JS, Gomi K, Blennerhassett MG, Bienenstock J. Nerve growth factor modifies the expression of inflammatory cytokines by mast cells via a prostanoid-dependent mechanism. J Immunol 1999;162:4271-6.

40. Horigome K, Pryor JC, Bullock ED, Johnson EM. Mediator release from mast cells by nerve growth factor. Neurotrophin specificity and receptor mediation. J Biol Chem 1993; 268:14881-7.

41. Lindsay RM, Harmar AJ. Nerve growth factor regulates expression of neuropeptide genes in adult sensory neurons. Nature 1989;337:362-4.

42. Aloe L, Levi-Montalcini R. Nerve growth factor induced overgrowth of axotomized superior cervical ganglia in neonatal rats. Similarities and differences with NGF effects in chemically axotomized sympathetic ganglia. Arch Ital Biol 1979;117:287-307.

43. Pearce FL, Thompson HL. Some characteristics of histamine secretion from rat peritoneal mast cells stimulated with nerve growth factor. J Physiol 1986;372:379-93.

44. Aloe L. The effect of nerve growth factor and its antibody on mast cells in vivo. J Neuroimmunol 1988;18:1-12.

45. Leon A, Buriani A, Dal Toso R, et al. Mast cells synthesize, store, and release nerve growth factor. Proc Natl Acad Sci USA 1994;91: 3739-43.

46. Marshall JS, Stead RH, McSharry C, et al. The role of mast cell degranulation products in mast cell hyperplasia. I. Mechanism of action of nerve growth factor. J Immunol 1990;144:1886-92.

47. Braun A, Quarcoo D, Schulte-Herbruggen O, et al. Nerve growth factor induces airway hyperresponsiveness in mice. Int Arch Allergy Immunol 2001;124:205-7.

48. Braun A, Lommatzsch M, Lewin GR, et al. Neurotrophins: a link between airway inflam- mation and airway smooth muscle contractility in asthma? Int Arch Allergy Immunol 1999; 118:163-5.

49. Villoslada P, Hauser SL, Bartke I, et al. Human nerve growth factor protects common marmosets against autoimmune encephalomyelitis by switching the balance of $\mathrm{T}$ helper cell type 1 and 2 cytokines within the central nervous system. J Exp Med 2000;191:1799-806.

50. Flugel A, Matsumuro K, Neumann H, et al. Anti-inflammatory activity of nerve growth factor in experimental autoimmune encephalomyelitis: inhibition of monocyte transendothelial migration. Eur J Immunol 2001;31:11-22.

51. Mousli M, Bronner C, Bockaert J, et al. Interaction of substance $\mathrm{P}$, compound $48 / 80$, and mastoparan with the alpha-subunit C-terminus of G protein. Immunol Lett 1990;25:355-7.

52. Mousli M, Hugli TE, Landry Y, Bronner C. Peptidergic pathway in human skin and rat peritoneal mast cell activation. Immunopharmacology 1994;27:1-11.

53. Severini C, Improta G, Falconieri-Erspamer G, et al. The tachykinin peptide family. Pharmacol Rev 2002;54:285-322.

54. Nakanishi S. Mammalian tachykinin receptors. Annu Rev Neurosci 1991;14:123-36.

55. Regoli D, Boudon A, Fauchere JL. Receptors and antagonists for substance $\mathrm{P}$ and related peptides. Pharmacol Rev 1994;46:551-99.

56. Kaltreider HB, Ichikawa S, Byrd PK, et al. Upregulation of neuropeptides and neuropeptide receptors in a murine model of immune inflammation in lung parenchyma. Am J Respir Cell Mol Biol 1997;16:133-44.

57. Mantyh CR, Vigna SR, Bollinger RR, et al. Differential expression of substance $P$ receptors in patients with Crohn's disease and ulcerative colitis. Gastroenterology 1995; 109:850-60.

58. Karimi K, Redegeld FA, Blom R, Nijkamp FP. Stem cell factor and interleukin-4 increase responsiveness of mast cells to substance P. Exp Hematol 2000;28:626-34.

59. Cooke HJ, Fox P, Alferes L, et al. Presence of NK1 receptors on a mucosal-like mast cell line, RBL-2H3 cells. Can J Physiol Pharmacol 1998;76:188-93. 
60. Okada T, Hirayama Y, Kishi S, et al. Functional neurokinin NK-1 receptor expression in rat peritoneal mast cells. Inflamm Res 1999;48:274-9.

61. Suzuki R, Furuno T, McKay DM, et al. Direct neurite-mast cell communication in vitro occurs via the neuropeptide substance P. J Immunol 1999;163:2410-5.

62. Mori N, Suzuki R, Furuno T, et al. Nerve-mast cell (RBL) interaction: RBL membrane ruffling occurs at the contact site with an activated neurite. Am J Physiol Cell Physiol 2002;283: C1738-44.

63. van der Kleij HP, Ma D, Redegeld FA, et al. Functional expression of neurokinin 1 receptors on mast cells induced by IL-4 and stem cell factor. J Immunol 2003;171:2074-9.

64. Furuno T, Ma D, van der Kleij HP, et al. Bone marrow-derived mast cells in mice respond in co-culture to scorpion venom activation of superior cervical ganglion neuritis according to level of expression of NK-1 receptors. Neurosci Lett 2004;372:185-9.

65. Bischoff SC, Schwengberg S, Lorentz A, et al. Substance $\mathrm{P}$ and other neuropeptides do not induce mediator release in isolated human intestinal mast cells. Neurogastroenterol Motil 2004;16:185-93.

66. Biro T, Maurer M, Modarres S, et al. Characterization of functional vanilloid receptors expressed by mast cells. Blood 1998;91:1332-40.

67. Paus R, Heinzelmann T, Robicsek S, et al. Substance $P$ stimulates murine epidermal keratinocyte proliferation and dermal mast cell degranulation in situ. Arch Dermatol Res 1995;287:500-2.

68. Barnes PJ. Neurogenic inflammation and asthma. J Asthma 1992;29:165-80.

69. Holzer P. Local effector functions of capsaicinsensitive sensory nerve endings: involvement of tachykinins, calcitonin gene-related peptide and other neuropeptides. Neuroscience 1988;24: 739-68.

70. Paus R, Peters EM, Eichmuller S, Botchkarev VA. Neural mechanisms of hair growth control. J Investig Dermatol Symp Proc 1997;2:61-8.

71. Gottwald T, Coerper S, Schaffer M, et al. The mast cell-nerve axis in wound healing: a hypothesis. Wound Repair Regen 1998;6:8-20.

72. Singh LK, Pang X, Alexacos N, et al. Acute immobilization stress triggers skin mast cell degranulation via corticotropin-releasing hormone, neurotensin, and substance P: a link to neurogenic skin disorders. Brain Behav Immun 1999;13:225-39.

73. Echtenacher B, Mannel DN, Hultner L. Critical protective role of mast cells in a model of acute septic peritonitis. Nature 1996;381:75-7.

74. Murphy PG, Borthwick LS, Johnston RS, et al. Nature of the retrograde signal from injured nerves that induces interleukin-6 mRNA in neurons. J Neurosci 1999:19;3791-800.

75. Nemmar A, Delaunois A, Beckers JF, et al. Modulatory effect of imetit, a histamine H3 receptor agonist, on C-fibers, cholinergic fibers, and mast cells in rabbit lungs in vitro. Eur $\mathbf{J}$ Pharmacol 1999;371:23-30.

76. Sekizawa S, Tsubone H, Kuwahara M, Sugano S. Does histamine stimulate trigeminal nasal afferents? Respir Physiol 1998;112:13-22.

77. Imamura M, Smith NC, Garbarg M, Levi R. Histamine H3-receptor-mediated inhibition of calcitonin gene-related peptide release from cardiac $\mathrm{C}$ fibers. A regulatory negative-feedback loop. Circ Res 1996;78:863-9.

78. Kashiba H, Fukui H, Morikawa Y, Senba E. Gene expression of histamine H1 receptor in guinea pig primary sensory neurons: a relationship between $\mathrm{H} 1$ receptor mRNA-expressing neurons and peptidergic neurons. Brain Res Mol Brain Res 1999;66:24-34.

79. Shubayev VI, Myers RR. Axonal transport of TNF-alpha in painful neuropathy: distribution of ligand tracer and TNF receptors. $J$ Neuroimmunol 2001;114:48-56.

80. Fischer A, McGregor GP, Saria A, et al. Induction of tachykinin gene and peptide expression in guinea pig nodose primary afferent neurons by allergic airway inflammation. J Clin Invest 1996;98:2284-91.

81. Undem BJ, Hubbard W, Weinreich D. Immunologically induced neuromodulation of guinea pig nodose ganglion neurons. J Auton Nerv Syst 1993;44:35-44.

82. Barnes PJ. Neurogenic inflammation in airways. Int Arch Allergy Appl Immunol 1991;94:303-9.

83. Lundberg JM, Brodin E, Hua X, Saria A. Vascular permeability changes and smooth muscle contraction in relation to capsaicin-sensitive substance $\mathrm{P}$ afferents in the guinea pig. Acta Physiol Scand 1984;120:217-27. 
84. Baluk P. Neurogenic inflammation in skin and airways. J Investig Dermatol Symp Proc 1997;2:76-81.

85. Maggi CA, Giachetti A, Dey RD, Said SI. Neuropeptides as regulators of airway function: vasoactive intestinal peptide and the tachykinins. Physiol Rev 1995;75:277-322.

86. Sann H, Dux M, Schemann M, Jancso G. Neurogenic inflammation in the gastrointestinal tract of the rat. Neurosci Lett 1996;219: 147-50.

87. Baraniuk JN, Kowalski ML, Kaliner MA. Relationships between permeable vessels, nerves, and mast cells in rat cutaneous neurogenic inflammation. J Appl Physiol 1990;68:2305-11.

88. Lundberg JM, Martling CR, Saria A. Substance $\mathrm{P}$ and capsaicin-induced contraction of human bronchi. Acta Physiol Scand 1983;119:49-53.

89. Sestini P, Dolovich M, Vancheri C, et al. Antigen-induced lung solute clearance in rats is dependent on capsaicin-sensitive nerves. Am Rev Respir Dis 1989;139:401-6.

90. Baird AW, Cuthbert AW. Neuronal involvement in type 1 hypersensitivity reactions in gut epithelia. Br J Pharmacol 1987;92:647-55.

91. Westerman RA, Low A, Pratt A, et al. Electrically evoked skin vasodilatation: a quantitative test of nociceptor function in man. Clin Exp Neurol 1987;23:81-9.

92. Undem BJ, Myers AC, Barthlow H, Weinreich D. Vagal innervation of guinea pig bronchial smooth muscle. J Appl Physiol 1990;69: 1336-46.

93. White DM. Release of substance P from peripheral sensory nerve terminals. J Peripher Nerv Syst 1997;2:191-201.

94. Bischoff SC, Baggiolini M, de Weck AL, Dahinden CA. Interleukin 8-inhibitor and inducer of histamine and leukotriene release in human basophils. Biochem Biophys Res Commun 1991;179:628-33.

95. Coleman JW, Holliday MR, Kimber I, et al. Regulation of mouse peritoneal mast cell secretory function by stem cell factor, IL-3 or IL-4. J Immunol 1993;150:556-62.

96. Janiszewski J, Bienenstock J, Blennerhassett MG. Picomolar doses of substance P trigger electrical responses in mast cells without degranulation. Am J Physiol 1994;267:C138-45.
97. van Houwelingen AH, Kool M, de Jager SC, et al. Mast cell-derived TNF-alpha primes sensory nerve endings in a pulmonary hypersensitivity reaction. J Immunol 2002;168:5297-302.

98. Theoharides TC, Kops SK, Bondy PK, Askenase PW. Differential release of serotonin without comparable histamine under diverse conditions in the rat mast cell. Biochem Pharmacol 1985;34:1389-98.

99. Ratliff TL, Klutke CG, Hofmeister M, et al. Role of the immune response in interstitial cystitis. Clin Immunol Immunopathol 1995;74:209-16.

100. Gottwald TP, Hewlett BR, Lhotak S, Stead RH. Electrical stimulation of the vagus nerve modulates the histamine content of mast cells in the rat jejunal mucosa. Neuroreport 1995;7:313-7.

101. Kandere-Grzybowska K, Letourneau R, Kempuraj D, et al. IL-1 induces vesicular secretion of IL-6 without degranulation from human mast cells. J Immunol 2003;171:4830-6.

102. Kraeuter Kops S, Theoharides TC, Cronin CT, et al. Ultrastructural characteristics of rat peritoneal mast cells undergoing differential release of serotonin without histamine and without degranulation. Cell Tissue Res 1990; 262:415-24.

103. Payan DG, Levine JD, Goetzl EJ. Modulation of immunity and hypersensitivity by sensory neuropeptides. J Immunol 1984;132:1601-4.

104. Elenkov IJ, Wilder RL, Chrousos GP, Vizi ES. The sympathetic nerve-an integrative interface between two supersystems: the brain and the immune system. Pharmacol Rev 2000:52; 595-638.

105. Cromlish JA, Seidah NG, Marcinkiewicz M, et al. Human pituitary tryptase: molecular forms, NH2-terminal sequence, immunocytochemical localization, and specificity with prohormone and fluorogenic substrates. J Biol Chem 1987;262:1363-73.

106. Silver R, Silverman AJ, Vitkovic L, Lederhendler II. Mast cells in the brain: evidence and functional significance. Trends Neurosci 1996;19:25-31.

107. Persinger MA. Brain mast cell numbers in the albino rat: sources variability. Behav Neural Biol 1979;25:380-6.

108. Silverman AJ, Millar RP, King JA, et al. Mast cells with gonadotropin-releasing hormone-like 
immunoreactivity in the brain of doves. Proc Natl Acad Sci USA 1994;91:3695-9.

109. Matsumoto I, Inoue Y, Shimada T, Aikawa T. Brain mast cells act as an immune gate to the hypothalamic-pituitary-adrenal axis in dogs. $\mathrm{J}$ Exp Med 2001;194:71-8.

110. Mares V, Bruckner G, Biesold D. Mast cells in the rat brain and changes in their number under different light regimens. Exp Neurol 1979;65:278-83.

111. MacQueen G, Marshall J, Perdue M, et al. Pavlovian conditioning of rat mucosal mast cells to secrete rat mast cell protease II. Science 1989;243:83-5.

112. Theoharides TC, Singh LK, Boucher W, et al. Corticotropin-releasing hormone induces skin mast cell degranulation and increased vascular permeability, a possible explanation for its proinflammatory effects. Endocrinology 1998; 139:403-13.

113. Black PH. Stress and the inflammatory response: a review of neurogenic inflammation. Brain Behav Immun 2002;16:622-53.

114. Castagliuolo I, Wershil BK, Karalis K, et al. Colonic mucin release in response to immobilization stress is mast cell dependent. Am J Physiol 1998;274:G1094-100.

115. Santos J, Saperas E, Nogueiras C, et al. Release of mast cell mediators into the jejunum by cold pain stress in humans. Gastroenterology 1998;114:640-8.

116. Rossi R, Johansson O. Cutaneous innervation and the role of neuronal peptides in cutaneous inflammation: a minireview. Eur J Dermatol 1998;8:299-306.

117. Ansel JC, Armstrong CA, Song I, et al. Interactions of the skin and nervous system. $\mathrm{J}$ Investig Dermatol Symp Proc 1997;2:23-6.

118. McDonald DM, Bowden JJ, Baluk P, Bunnett NW. Neurogenic inflammation. A model for studying efferent actions of sensory nerves. Adv Exp Med Biol 1996;410:453-62.

119. Scholzen T, Armstrong CA, Bunnett NW, et al. Neuropeptides in the skin: interactions between the neuroendocrine and the skin immune systems. Exp Dermatol 1998;7:81-96.

120. Church MK, Okayama Y, el-Lati S. Mediator secretion from human skin mast cells provoked by immunological and non-immunological stimulation. Skin Pharmacol 1991;4:15-24.
121. Ansel JC, Brown JR, Payan DG, Brown MA. Substance P selectively activates TNF-alpha gene expression in murine mast cells. J Immunol 1993;150:4478-85.

122. Hart PH, Jaksic A, Swift G, et al. Histamine involvement in UVB- and cis-urocanic acidinduced systemic suppression of contact hypersensitivity responses. Immunology 1997;91:601-8.

123. Hart PH, Grimbaldeston MA, Swift GJ, et al. Dermal mast cells determine susceptibility to ultraviolet B-induced systemic suppression of contact hypersensitivity responses in mice. $\mathrm{J}$ Exp Med 1998;187:2045-53.

124. Alard P, Niizeki H, Hanninen L, Streilein JW. Local ultraviolet B irradiation impairs contact hypersensitivity induction by triggering release of tumor necrosis factor-alpha from mast cells: involvement of mast cells and Langerhans cells in susceptibility to ultraviolet B. J Invest Dermatol 1999;113: 983-90.

125. Yoshikawa T, Streilein JW. Tumor necrosis factor-alpha and ultraviolet B light have similar effects on contact hypersensitivity in mice. Reg Immunol 1990-91;3:139-44.

126. Solway J, Leff AR. Sensory neuropeptides and airway function. J Appl Physiol 1991;71: 2077-87.

127. Ollerenshaw SL, Jarvis D, Sullivan CE, Woolcock AJ. Substance P immunoreactive nerves in airways from asthmatics and nonasthmatics. Eur Respir J 1991;4:673-82.

128. Nieber K, Baumgarten CR, Rathsack R, et al. Substance $\mathrm{P}$ and beta-endorphin-like immunoreactivity in lavage fluids of subjects with and without allergic asthma. J Allergy Clin Immunol 1992;90:646-52.

129. Lilly CM, Hall AE, Rodger IW, et al. Substance P-induced histamine release in tracheally perfused guinea pig lungs. J Appl Physiol 1995;78:1234-41.

130. Howarth PH, Djukanovic R, Wilson JW, et al. Mucosal nerves in endobronchial biopsies in asthma and non-asthma. Int Arch Allergy Appl Immunol 1991;94:330-3.

131. Cardell LO, Uddman R, Edvinsson L. Low plasma concentrations of VIP and elevated levels of other neuropeptides during exacerbations of asthma. Eur Respir J 1994;7:2169-73. 
132. Tomaki M, Ichinose M, Miura M. Elevated substance $\mathrm{P}$ content in induced sputum from patients with asthma and patients with chronic bronchitis. Am J Respir Crit Care Med 1995;151:613-7.

133. Forsythe P, McGarvey LP, Heaney LG, et al. Sensory neuropeptides induce histamine release from bronchoalveolar lavage cells in both nonasthmatic coughers and cough variant asthmatics. Clin Exp Allergy 2000;30:225-32.

134. Stead RH, Dixon MF, Bramwell NH, et al. Mast cells are closely apposed to nerves in the human gastrointestinal mucosa. Gastroenterology 1989;97:575-85.

135. Shanahan F, Denburg JA, Fox J, et al. Mast cell heterogeneity: effects of neuroenteric peptides on histamine release. J Immunol 1985;135: 1331-7.

136. Barbara G, Stanghellini V, De Giorgio R, et al. Activated mast cells in proximity to colonic nerves correlate with abdominal pain in irritable bowel syndrome. Gastroenterology 2004;126:693-702.

137. Jiang W, Kreis ME, Eastwood C, et al. 5-HT3 and histamine $\mathrm{H} 1$ receptors mediate afferent nerve sensitivity to intestinal anaphylaxis in rats. Gastroenterology 2000;119:1267-75.

138. McKay DM, Bienenstock J. The interaction between mast cells and nerves in the gastrointestinal tract. Immunol Today 1994;15:533-8.

139. Perdue MH, Masson S, Wershil BK, Galli SJ. Role of mast cells in ion transport abnormalities associated with intestinal anaphylaxis: correction of the diminished secretory response in genetically mast cell-deficient $\mathrm{W} / \mathrm{Wv}$ mice by bone marrow transplantation. J Clin Invest 1991;87:687-93.

140. Javed NH, Wang YZ, Cooke HJ. Neuroimmune interactions: role for cholinergic neurons in intestinal anaphylaxis. Am J Physiol 1992;263: G847-52.
141. Wershil BK, Castagliuolo I, Pothoulakis C. Direct evidence of mast cell involvement in Clostridium difficile toxin A-induced enteritis in mice. Gastroenterology 1998;114:956-64.

142. Castagliuolo I, LaMont JT, Letourneau R, et al. Neuronal involvement in the intestinal effects of Clostridium difficile toxin A and Vibrio cholerae enterotoxin in rat ileum. Gastroenterology 1994;107:657-65.

143. Barnes PJ. Cytokine modulators as novel therapies for airway disease. Eur Respir J Suppl 2001;34:67s-77s.

144. Toyoda M, Morohashi M. Morphological assessment of the effects of cyclosporin A on mast cell-nerve relationship in atopic dermatitis. Acta Derm Venereol 1998;78:321-5.

145. Mazelin L, Theodorou V, Fioramonti J, Bueno L. Vagally dependent protective action of calcitonin gene-related peptide on colitis. Peptides 1999;20:1367-74.

146. Reinshagen M, Patel A, Sottili M, et al. Action of sensory neurons in an experimental rat colitis model of injury and repair. Am J Physiol 1996;270(1 Pt 1):G79-86.

147. Miampamba M, Sharkey KA. Distribution of calcitonin gene-related peptide, somatostatin, substance $P$, and vasoactive intestinal polypeptide in experimental colitis in rats. Neurogastroenterol Motil 1998;10:315-29.

148. Lambrecht BN, Germonpre PR, Everaert EG, et al. Endogenously produced substance $\mathrm{P}$ contributes to lymphocyte proliferation induced by dendritic cells and direct TCR ligation. Eur J Immunol 1999;29:3815-25.

149. Weinstock JV, Blum A, Walder J, Walder R. Eosinophils from granulomas in murine schistosomiasis mansoni produce substance $\mathrm{P}$. $\mathrm{J}$ Immunol 1988;141:961-6.

150. Maggi CA. The effects of tachykinins on inflammatory and immune cells. Regul Pept 1997;70:75-90. 